\title{
Penicillium species as a rare isolate in tracheal granulation tissue: a
}

\section{case series}

\author{
Premjit S Randhawa*1,2, SA Reza Nouraei ${ }^{1}$, David J Howard ${ }^{2}$, \\ Gurpreet S Sandhu ${ }^{1,2}$ and Michael A Petrou ${ }^{3}$
}

\begin{abstract}
Address: ${ }^{1}$ Department of Otolaryngology, Charing Cross Hospital, London, UK, ${ }^{2}$ Royal National Throat Nose and Ear Hospital, London, UK and ${ }^{3}$ Department of Medical Mycology, Hammersmith Hospital, London, UK

Email: Premjit S Randhawa* - prandhawa13@hotmail.com; SA Reza Nouraei -rn@cantab.net; David J Howard - v.lund@ucl.ac.uk; Gurpreet S Sandhu - g.sand@btinternet.com; Michael A Petrou - m.petrou@imperial.ac.uk

* Corresponding author
\end{abstract}

Published: 17 March 2008

Journal of Medical Case Reports 2008, 2:84 doi:10.1186/1752-1947-2-84
Received: 6 September 2007

Accepted: 17 March 2008

This article is available from: http://www.jmedicalcasereports.com/content/2/l/84

(C) 2008 Randhawa et al; licensee BioMed Central Ltd.

This is an Open Access article distributed under the terms of the Creative Commons Attribution License (http://creativecommons.org/licenses/by/2.0), which permits unrestricted use, distribution, and reproduction in any medium, provided the original work is properly cited.

\begin{abstract}
Introduction: Granulation tissue formation is a major problem complicating the treatment of upper airway stenosis. We present two cases of recurrent tracheal granulation tissue colonisation by Penicillium species in patients undergoing laryngotracheal reconstructive surgery for postintubation tracheal stenosis. We believe that although most Penicillium species do not cause invasive disease they can be a contributory factor to the occurrence of upper airway stenosis.
\end{abstract}

Case presentation: A microbiological and mycological study of tracheal granulation tissue in two patients with recurrent laryngotracheal stenosis was carried out. Penicillium species was seen microscopically and cultured from tracheal granulation tissue. Neither patient grew any bacteria known to be associated with airway granulation tissue formation. Amphotericin B, itraconazole, flucytosine voriconazole and caspofungin were highly active against both isolates.

Conclusion: A search for a fungal cause should form part of the investigation for recurrent tracheal granulation tissue during laryngotracheal reconstruction.

\section{Introduction}

The commonest cause of upper airway stenosis in all age groups is post-intubation tracheal injury. This condition causes significant pulmonary morbidity and, if left untreated, may progress to life-threatening airway compromise. A major problem encountered during laryngotracheal reconstruction is the formation of airway granulation tissue.

Bacteria such as Pseudomonas aeruginosa and Staphylococcus aureus have been associated with airway granulation tissue formation [1-3], and local and systemic antibiotic prophylaxis for these organisms has been recommended [4]. However there remains a cohort of patients with recurrent airway granulation tissue, in whom no evidence of bacterial infection or foreign body reaction can be identified.

We describe two cases of biopsy-proven Penicillium species isolated from tracheal granulation tissue in patients with recurrent airway granulation tissue. 


\section{Case presentation Case I}

A previously healthy 60-year-old male was intubated for a two-week period following myocardial infarction and as a consequence developed a $3.6 \mathrm{~cm}$ tracheal stenosis below the vocal cords. He underwent several microlaryngoscopy, laser and dilatation procedures to restore airway lumen, and had a soft silastic stent in situ to maintain luminal patency. However, he continued to have recurrent airway granulation tissue. A sample of the granulomatous tissue and the airway stent were taken and sent for microbiological and mycological investigations. No bacterial cause for the granulation tissue was identified; however, direct microscopy of the homogenised tissue showed septate hyphae pathognomonic of Penicillium species. In view of the recurring and florid nature of the granulation tissue, it was felt that the best long-term outcome would be an enbloc tracheal resection with end-to-end anastomosis. The patient underwent the procedure successfully and has had no further problems with his airway. As he had a definitive and successful procedure, he did not require antimicrobial treatment.

\section{Case 2}

A 46-year-old male acquired a subglottic stenosis following a 10-day period of intubation after surgical clipping of a cerebral aneurysm, having acutely presenting with a subarachnoid haemorrhage. He underwent microlaryngoscopy, treatment with potassium-titanyl-phosphate (KTP) laser and stenting to improve his airway. Two months later he underwent repeat microlaryngoscopy and removal of the tracheal stent, at which point florid airway granulation tissue was noted (Figure 1). A sample of the granulomatous tissue and the stent were taken. Again, as in the first case, septate hyphae were seen microscopically and only Penicillium species were isolated. This patient subsequently underwent further microlaryngoscopy and laser therapy to the granulation tissue in his airway with significant improvement. In view of the significant improvement in his airway, antimicrobials were felt to be unnecessary.

\section{Method of tissue culturing}

The tissue was obtained from the patients undergoing microlaryngoscopy under a general anaesthetic with an endotracheal tube in place. Biopsies were obtained from the granulomatous tissue and immediately dispatched to the department of mycology in sterile saline. The tissue was cut into smaller pieces and homogenised by drudging it onto a grid that was scarred in the middle of a sterile Petri dish with a sterile scalpel. The tissue was subsequently suspended in $1 \mathrm{ml}$ of sterile distilled water. This technique has been described and used successfully by Nouraei et al [5] in their work on bacterial colonisation of airway stents.
The resulting suspension was inoculated onto blood agar aerobically and anaerobically, Maconkey agar, Neomycin blood agar anaerobically with a metronidazole disc added on the streak $2 \mathrm{~cm}$ away from the inoculum, chocolate agar under $10 \%$ carbon dioxide $\left(\mathrm{CO}_{2}\right)$ and Sabouraud's dextrose agar at 30 and $37^{\circ} \mathrm{C}$. The plates were incubated and were examined for growth after 2, 5 and 7 days incubation. The suspension was also treated with $20 \%$ potassium hydroxide $(\mathrm{KOH})$ for 30 minutes after which a drop of calcofluor white was added and the suspension was examined using a fluorescent microscope. A slide was also prepared for Gram staining and this was examined with the aid of a light microscope using an oil immersion.

\section{Results}

Scanty normal mouth flora was obtained from the granulation tissue of both patients and a heavy growth of Penicillium species was obtained only at $30^{\circ} \mathrm{C}$ in both cases. Following reincubation at $30^{\circ} \mathrm{C}$, Penicillium species was grown on all of the plates without exception. The minimum inhibitory concentrations (MIC) to amphotericin B, flucytosine, fluconazole, itraconazole, voriconazole and caspofungin for both isolates were performed according to the Clinical Laboratory Standard Institute (CLSI, previously known as NCCLS) guidelines with a minor modification [6] and were incubated at $30^{\circ} \mathrm{C}$ until appreciable growth was achieved to be able to distinguish between growth and inhibition.

Enquiries were made to have the two isolates genotyped by molecular techniques; however, at present no such techniques are available for Penicillium species.

\section{Discussion}

Airway granulation is a common and troublesome problem during laryngotracheal reconstruction. It leads to recurrent narrowing of the airway lumen and symptomatic relapse, which often can delay definitive surgical management $[1,2]$. Airway stents are commonly deployed in this setting to maintain luminal patency, but many patients continue to form granulation tissue, in part because of the presence of the airway stents themselves [7].

The development of granulation tissue has been associated with a number of factors notably mechanical irritation and microbial infection with bacteria such as $P$. aeruginosa and $S$. aureus [5], as well as fungi such as Candida species $[1,2,8]$. It has furthermore been shown that treatment of these infections reduces the incidence of granulation tissue formation [4], but there remains a small number of patients who continue to form airway granulation tissue with no apparent underlying cause. 


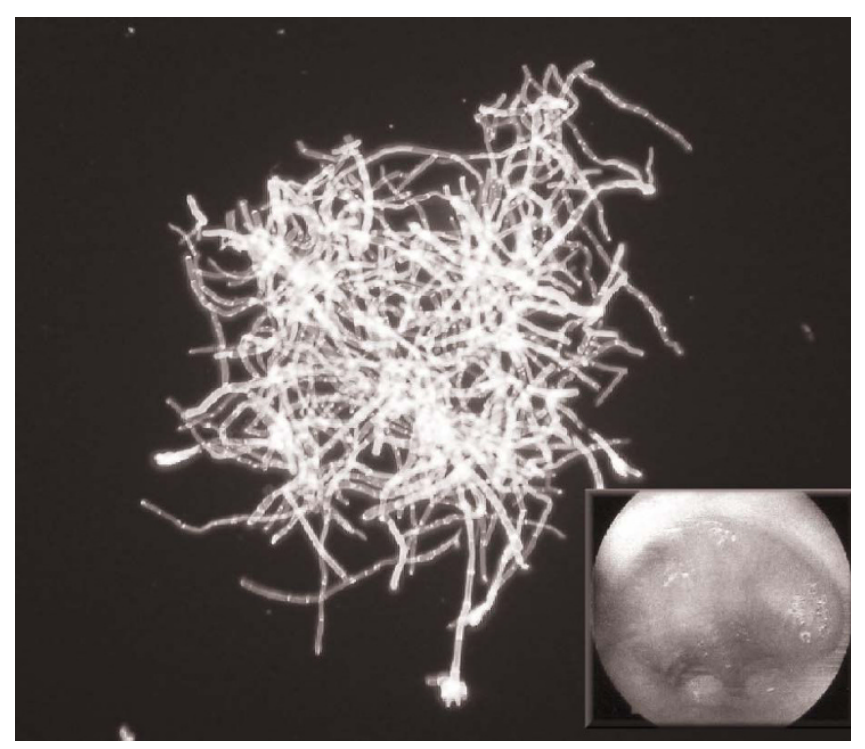

Figure I

Microscopic appearance of Penicillium species grown from tracheal granulation tissue. The inset shows the endoscopic appearance of tracheal granulation tissue.

In this study we isolated Penicillium species from two such patients, one year apart, with post-intubation tracheal stenosis and a clinical picture of recurrent airway granulation tissue associated with silastic airway stents. Penicillium species are ubiquitous and their spores are spread by wind and insects and are usually regarded as unimportant in terms of causing disease. Most Penicillium species are plant pathogens and are responsible for the spoilage of fruit and are incapable of growing at temperatures above $30^{\circ} \mathrm{C}$. Penicillium can occasionally cause infection in humans, particularly in immunocompromised hosts, and the resulting infections are generically known as Penicilliosis. They have been isolated from patients with brain abscesses [9], necrotising oesophagitis [10], pneumonia and lung nodules [11], bone marrow [12], keratitis and conjunctivitis [13], otomycosis, endocarditis, peritonitis and urinary tract infections.

In both of our immunocompetent patients, hyphae consistent with Penicillium were seen on direct microscopy, where the brush-like appearance of the penicillus was evident. Penicillium species were isolated from both patients' granulation tissue (Figure 1). To the best of the authors' knowledge this has not been described in the literature previously. Both isolates were unable to grow above $35^{\circ} \mathrm{C}$ suggesting that neither was capable of causing deep tissue invasive disease. The granulation tissue observed could be a result of superficial growth where the temperature remained below $35^{\circ} \mathrm{C}$ or a result of toxic by-products produced during the growth of the Penicillium biofilm (Figure $1)$.
With the exception of fluconazole (MIC $>64 \mu \mathrm{g} / \mathrm{ml}$ ), the isolates were inhibited by low concentrations of amphotericin B (MICs 0.012, 0.06), flucytosine (MICs 2, 0.25), itraconazole (MICs 0.01, 0.03), voriconazole (MICs 0.03, 0.02 ) and caspofungin (effective at $0.007 \mu \mathrm{g} / \mathrm{ml}$ ). This suggests that these isolates are very easy to treat with appropriate antifungals, particularly the two triazoles (itraconazole and voriconazole) which are both available as oral agents. In both of our cases, the surgical removal of the granulomatous tissue has been sufficient and neither patient required antifungal treatment. However, should the granulation tissue have recurred, suggesting this was an invasive disease by an organism that in vitro cannot grow at body temperature but possibly is able to grow in vivo, which is not uncommon with some fungi, we would have opted for an oral antifungal such as itraconazole or voriconazole.

\section{Conclusion}

We demonstrated growth of Penicillium species in two patients with a clinical history of recurrent airway granulation during treatment of post-intubation tracheal injury. If surgical intervention proves inadequate to eradicate the granulation, microbial causes need to be considered. We propose that a search for a fungal aetiology should be undertaken in patients with recurrent airway granulation in whom a first-line bacterial cause for the granulation cannot be identified. To this end we recommend that specimens should be cultured both at $28-30^{\circ} \mathrm{C}$, as well as at $37^{\circ} \mathrm{C}$, as many fungal species, including both of our isolates, do not grow above $30^{\circ} \mathrm{C}$. This case illustrates that fungi that are normally considered as contaminants, such as Penicillium species, should not be dismissed as a possible aetiological factor to the formation of granulation tissue in the trachea.

\section{Competing interests}

The author(s) declare that they have no competing interests.

\section{Authors' contributions}

PSR and SARN were responsible for drafting the manuscript. MAP, DJH and GSS performed critical revision of the manuscript for important intellectual content. PSR, SARN and MAP provided administrative, technical and material support. DJH and GSS supervised the study.

\section{Consent}

Written informed consent was obtained from both patients for publication of these case reports and accompanying images. A copy of the written consent is available for review by the Editor-in-Chief of this journal. 


\section{References}

I. Schmal F, Fegeler W, Terpe HJ, Hermann W, Stoll W, Becker K: Bacteria and granulation tissue associated with Montgomery $\mathrm{T}$ tubes. Laryngoscope 2003, I I 3: I 394- I400.

2. Simoni $P$, Wiatrak BJ: Microbiology of stents in laryngotracheal reconstruction. Laryngoscope 2004, I | 4:364-366.

3. Noppen M, Pierard D, Meysman M, Claes I, Vincken W: Bacterial colonization of central airways after stenting. Am J Respir Crit Care Med 1999, 160:672-677.

4. Sasaki CT, Horiuchi M, Koss N: Tracheostomy-related subglottic stenosis: bacteriologic pathogenesis. Laryngoscope 1979, 89:857-865.

5. Nouraei SA, Petrou MA, Randhawa PS, Singh A, Howard DJ, Sandhu GS: Bacterial colonization of airway stents: a promoter of granulation tissue formation following laryngotracheal reconstruction. Arch Otolaryngol Head Neck Surg 2006, I32:1086-1090 [http://www.ncbi.nlm.nih.gov/sites/ent rez?Db=pubmed\&Cmd=Search\&Term=\%22Randhawa\%20PS\%22BA uthor\%5D\&itool=EntrezSystem 2.PEnt

rez.Pubmed.Pubmed ResultsPanel.Pubmed RVAbstractPlus].

6. Petrou MA, Shanson DC: Susceptibility of Cryptococcus neoformans by the NCCLS microdilution and Etest methods using five defined media. J Antimicrob Chemother 2000, 46:815-8I8.

7. Noppen M, Pierard D, Meysman M, Herreweghe RV, Vincken W: Absence of bacterial colonization of the airways after therapeutic rigid bronchoscopy without stenting. Eur Respir J 2000, I6:||47-||5|.

8. Matt BH, Myer CM, Harrison CJ, Reising SF, Cotton RT: Tracheal granulation tissue. A study of bacteriology. Arch Otolaryngol Head Neck Surg 199I, I I 7:538-54I.

9. Noritomi DT, Bub GL, Beer I, da Silva AS, de Cleva R, Gama-Rodrigues JJ: Multiple brain abscesses due to Penicillium spp infection. Rev Inst Med Trop Sao Paulo 2005, 47: I67-I70.

10. Hoffman M, Bash E, Berger SA, Burke M, Yust I: Fatal necrotizing esophagitis due to Penicillium chrysogenum in a patient with acquired immunodeficiency syndrome. Eur J Clin Microbiol Infect Dis 1992, I I:I I58-1 I60.

II. Liebler GA, Magovern G], Sadighi P, Park SB, Cushing WJ: Penicillium granuloma of the lung presenting as a solitary pulmonary nodule. JAMA 1997, 237:67I.

12. So CC, Wong KF: Bone marrow penicilliosis. Br J Haematol 2002, I I 7:777.

13. Miguelez S, Obrador P, Vila J: Conjunctival infection due to Penicillium sp. Arch Soc Esp Oftalmol 2003, 78:55-57.

Publish with Biomed Central and every scientist can read your work free of charge

"BioMed Central will be the most significant development for disseminating the results of biomedical research in our lifetime. "

Sir Paul Nurse, Cancer Research UK

Your research papers will be:

- available free of charge to the entire biomedical community

- peer reviewed and published immediately upon acceptance

- cited in PubMed and archived on PubMed Central

- yours - you keep the copyright

Submit your manuscript here:

http://www.biomedcentral.com/info/publishing_adv.asp
BioMedcentral 